\title{
INTERACTION BETWEEN SACCHAROMYCES CEREVISIAE AND CHRYSOTILE
}

\author{
Flavia Cassiola $^{1}$, Marina Silveira ${ }^{2}$, Soraya Jericó ${ }^{1}$ and Inés Joekes ${ }^{1 *}$ \\ ${ }^{1}$ Instituto de Química - Universidade Estadual de Campinas \\ ${ }^{2}$ Laboratório de Microscopia Eletrônica, Instituto de Física, Universidade de São Paulo
}

\begin{abstract}
The interaction between Saccharomyces cerevisiae and chrysotile fibers was studied by scanning electron microscopy. The yeast cells adhere preferentially to the fibrils. In the extreme case, all the adhered fibrils were broken, resulting in a complete coverage of the surface. The chrysotile covered cells showed less buds, but retained metabolic capacities, and were fully active in fermentation experiments after one year. The interaction degree was depending on contact time and adhesion medium. The longer the contact period, the stronger the interaction between the cells and the fibers. Cells adhered in water show poor entrapment after short contact time, but were highly entrapped after longer periods and did not show any agglomerates. Cells adhered in the presence of nutrients showed a lower entrapment and a higher degree of cellular growth.
\end{abstract}

Key Words: Saccharomyces cerevisiae/chrysotile, chrysotile adhesion, cell/fiber interaction, scanning electron microscopy, yeast metabolism.

\footnotetext{
*Address for correspondence:

Inés Joekes

Department of Physical Chemistry

Instituto de Química

Universidade de Campinas

Caixa Postal 6154 - 13083-970

Campinas, SP, Brazil
}

Telephone number: (55) (19) 7883094

Fax: number: (55) (19) 7883094

E-mail: ines@iqm.unicamp.br

\section{Introduction}

Brazilian industrial ethanol production is about 12 billion litres per year, using sugar cane as raw material. A number of process improvements have been made in recent years, mostly related to strain selection. However, even nowadays the current production is based on batch or semicontinuous processes. We have shown that Saccharomyces cerevisiae supported by chrysotile has a 1.3 -fold increase in fermentation velocity and that ethanol yield can be as much as $26 \%$ higher than for the free cells (Joekes $e t$ $a l ., 1998)$. Thus, this system could be used in a continuous fermentation process (Wendhausen et al., 1998).

Chrysotile is a fibrillar magnesium silicate abundant in Brazil. Ores in this country are uncontaminated by dangerous asbestos forms as crocidolite, tremolite and amosite. A number of papers have been published about the interaction between chrysotile and biological materials, since it is well known that these fibres can cause lung diseases. Among all the natural asbestos materials, which include the amphiboles crocidolite, tremolite, amosite, anthophillite and actinolite, and the serpentines antigorite, picrolite and chrysotile, lung cancer is associated with crocidolite (blue asbestos), tremolite and amosite (brown asbestos) (Nolan et al., 1994), whereas the other fibres vary in degree of health hazard (Broaddus, 1997). Chrysotile is less biopersistent than the amphiboles (Langer and Nolan, 1994). It is reportedly dissolved in lung and pleural cells (Kogan and Nikitina, 1994), and therefore less hazardous. However, controversy about asbestos disease risk continues (Cullen, 1998), focusing on the fibre length and aggregation state. Electron microscopy studies, mostly by transmission electron microscopy, use samples of lung tissue, both from humans and rats, in which the biological material had been dissolved, in order to identify, count and characterize the fibers. Up to now, only one research laboratory has published results on scanning electron microscopy and transmission electron microscopy of ultrathin sections of rat and mouse macrophages (Fukumori et al., 1995, 1996, 1997). So, the use of chrysotile as catalyst support in a large scale industrial process can be considered safe.

Saccharomyces cerevisiae adheres strongly to chrysotile. Preliminary scanning electron microscopy results showed that the cells are attached to microfibres, in a way resembling a silk-nest (Joekes et al., 1998). As far as we know, this is a novelty in terms of cell attachment. After adhesion onto chrysotile, the cells show fermentation activity for as long as one year, even when kept in a standard refrigerator. The nature of the interaction may explain this and other unexpected metabolic alterations, namely 
increased thermal tolerance and diminished reproduction rate. In this work we show SEM results obtained studying the adhesion of yeast on chrysotile as a function of time and media.

\section{Experimental}

\section{Adhesion method}

Chrysotile 5R (Quebec Standard) obtained from SAMA Mineração de Amianto Ltda (Minaçu, GO, Brazil) was washed with tap water and activated by sonication at controlled $\mathrm{pH}$ (4.7) as described elsewhere (Parizotto et al., 1989).

The Saccharomyces cerevisiae strains FEA01 and CCT3174 were studied. These strains were previously selected as being those that gave the best yields in sugar cane fermentation when adhered onto chrysotile.

Two grams of activated chrysotile were dispersed in $100 \mathrm{~mL}$ distilled water $(\mathrm{W})$ or $5 \%(\mathrm{w} / \mathrm{v})$ sugarcane syrup solution (S) then sterilized $\left(120^{\circ} \mathrm{C}, 15 \mathrm{~min}\right)$. After cooling, Saccharomyces cerevisiae (FEA01), obtained from Faculdade de Engenharia de Alimentos - UNICAMP (Campinas SP, Brazil), was inoculated at $30 \pm 0.1^{\circ} \mathrm{C}$ and stirred for $24 \mathrm{~h}$. The suspensions (samples $\mathrm{W}$ and $\mathrm{S}$ ) were sieved (170 mesh) and washed with $2 \mathrm{~L}$ distilled water.

Saccharomyces cerevisiae (CCT 3174), obtained from Fundação Tropical André Tosello (Campinas SP, Brazil) was grown in a sterilized $\left(120^{\circ} \mathrm{C}, 15 \mathrm{~min}\right)$ solution containing 10 $\mathrm{g} \mathrm{L}^{-1} \mathrm{D}$-glucose, $5 \mathrm{~g} \mathrm{~L}^{-1}$ peptone, $3 \mathrm{~g} \mathrm{~L}^{-1}$ malt extract and $3 \mathrm{~g}$ $\mathrm{L}^{-1}$ yeast extract. After 2 days, the suspension was centrifuged ( $2500 \mathrm{rpm}, 15 \mathrm{~min}$ ), suspended in sterilized water $\left(0.500 \mathrm{~L}^{-1}\right)$ and filtered (Buchner with filter paper) to obtain the yeast. One gram of activated chrysotile and $0.6 \mathrm{~g}$ of cells were dispersed in $200 \mathrm{~mL}$ of distilled water, stirred for $15 \mathrm{~min}$, sieved (200 mesh) and washed with water, sample W(-). One gram of activated chrysotile was dispersed in $200 \mathrm{~mL}$ of distilled water, stirred for $10 \mathrm{~min}$ and sterilized $\left(120^{\circ} \mathrm{C}, 15 \mathrm{~min}\right)$. After cooling, $0.6 \mathrm{~g}$ of the cells were added with mild stirring for $10 \mathrm{~min}$, and the suspension was sieved (200 mesh). The cake was kept in an Erlenmeyer flask, covered with beads to avoid buoyancy and $1.5 \mathrm{~L}$ of fermentation medium containing $30 \%(\mathrm{w} / \mathrm{v}) \mathrm{D}$-glucose, $0.5 \mathrm{~g} \mathrm{~L}^{-1}$ $\mathrm{MgSO}_{4} \cdot 7 \mathrm{H}_{2} \mathrm{O}$ and $3.0 \mathrm{~g} \mathrm{~L}^{-1}$ urea was added. The $\mathrm{pH}$ of this solution was adjusted to 5.0 with phosphoric acid. The flask was sealed with a rubber stopper pierced by a needle and placed during 4 days in a thermostatically-controlled shaker at $30.0 \pm 0.1{ }^{\circ} \mathrm{C}$. The suspension was sieved (200 mesh) and washed with water, sample $\mathrm{S}(+)$. These samples are summarized in Table 1.

\section{Sample preparation for scanning electron microscopy (SEM)}

Saccharomyces cerevisiae / chrysotile samples were separated into two portions before handling. One was handled as usual. The second was protected with a nylon gaze (ca. $0.5 \mathrm{~mm}$ opening) to avoid losing of cells during handling. Both sets were fixed in a phosphate-buffered $(0.1$ mol L-1 $\mathrm{pH}$ 7) $2.5 \% \mathrm{v} / \mathrm{v}$ glutaraldehyde solution by gently shaking for $2 \mathrm{~h}$ at $4^{\circ} \mathrm{C}$ and rinsed in the same buffer. Postfixation was carried out in $1 \%$ osmium tetroxide in phosphate buffer by gently shaking for $2 \mathrm{~h}$ at room temperature. The samples were washed 10-times in distilled water and dehydrated through a graded series of ethanol solutions $(50,70,80,95,100 \% \mathrm{v} / \mathrm{v})$, dried by the critical point method with $\mathrm{CO}_{2}$, mounted on stubs and sputter coated with gold $(4 \mathrm{~nm})$. SEM observations were made in a JEOL JSM-840A (Japan) scanning electron microscope at an accelerating voltage of $25 \mathrm{kV}$.

\section{Results and Discussion}

No significant difference in behavior was found between strains FEA01 and CCT3174, as regards the adhesion process. Figure 1 shows SEM micrographs of cells adhered to chrysotile fibrils in the presence (A to E) and in the absence $(\mathrm{F})$ of nutrients. Cells that are strongly and cells that are poorly adhered to the fibrils can be distinguished. All chrysotile/cell systems examined a week after the adhesion time showed little chrysotile/cell interaction. In Figure 1A, cells that had been in contact with chrysotile for 8 days, during sample storage, are shown. No fibre entrapment was observed, only agglomerates with bonded cells and scars in the cell wall due to budding growth. In Figures $1 \mathrm{~B}$ to $1 \mathrm{~F}$ cells were in contact with the fibres for 60 days in a refrigerator $\left(4^{\circ} \mathrm{C}\right)$, and appear much more entrapped by the fibrils.

During the storage period neither nutrients nor water were supplied. Even so, the cells reproduced by a budding process, as evidenced by the wall-bound cells in Figures $1 \mathrm{~B}$ and $\mathrm{C}$. The budding growth process induces a state of cellular agglomeration. These agglomerations, with cells poorly adhered to the fibrils, were preserved through the use of a nylon net during sample preparation. As expected, only the cells deeply entrapped by fibrils, forming a sort of silkworm cocoon, can be observed in samples fixed without the nylon net, as in Figures 1D and 1E whereas all poorly entrapped cells were lost during sample preparation. The estimated number of strongly entrapped cells in these 60 -day-storage samples is about $10 \%$.

\begin{tabular}{l|l|l|c}
\hline Sample & Strain & Adhesion medium & Adhesion time \\
\hline $\mathrm{W}$ & FEA01 & distilled water & $24 \mathrm{~h}$ \\
$\mathrm{~S}$ & FEA01 & sugarcane syrup solution $5^{\circ} \mathrm{Bx}(5 \%$ soluble solids $)$ & $24 \mathrm{~h}$ \\
$\mathrm{~W}(-)$ & $\mathrm{CCT} 3174$ & distilled water & $15 \mathrm{~min}$ \\
$\mathrm{~S}(+)$ & $\mathrm{CCT} 3174$ & fermentation medium: $30 \%(\mathrm{w} / \mathrm{v}) \mathrm{D}-\mathrm{glucose}, 0.5 \mathrm{~g}$ & $96 \mathrm{~h}$ \\
& & $\mathrm{~L}^{-1} \mathrm{MgSO}_{4} \cdot 7 \mathrm{H}_{2} \mathrm{O}$ and $3.0 \mathrm{~g} \mathrm{~L}-1$ urea, $\mathrm{pH} 5.0$ & \\
\hline
\end{tabular}

Table 1 - Adhesion medium and adhesion time of the samples of Saccharomyces cerevisiae onto chrysotile described in this work. 

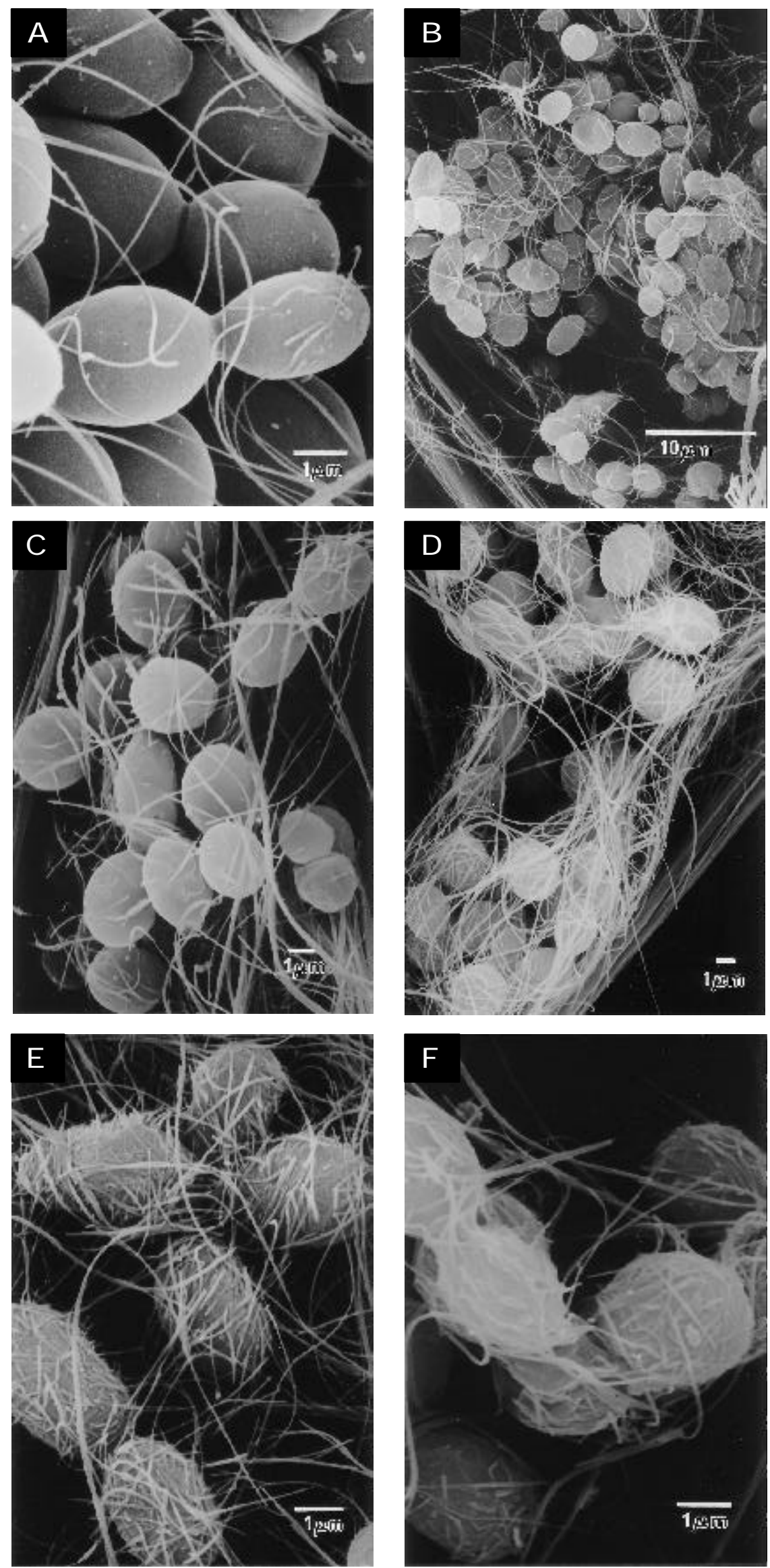

Figure 1: Scanning electron micrographs of Saccharomyces cerevisiae adhered onto chrysotile, showing differences in entrapment, agglomeration and budding as a function of contact time and adhesion medium. Samples $\mathrm{S}$ (A to E) and W (F). Samples processed within a nylon net (A, B, C and F) or samples processed freely (D and E), following 8 days (A) and 60 days (B to $\mathrm{F}$ ) of contact. 

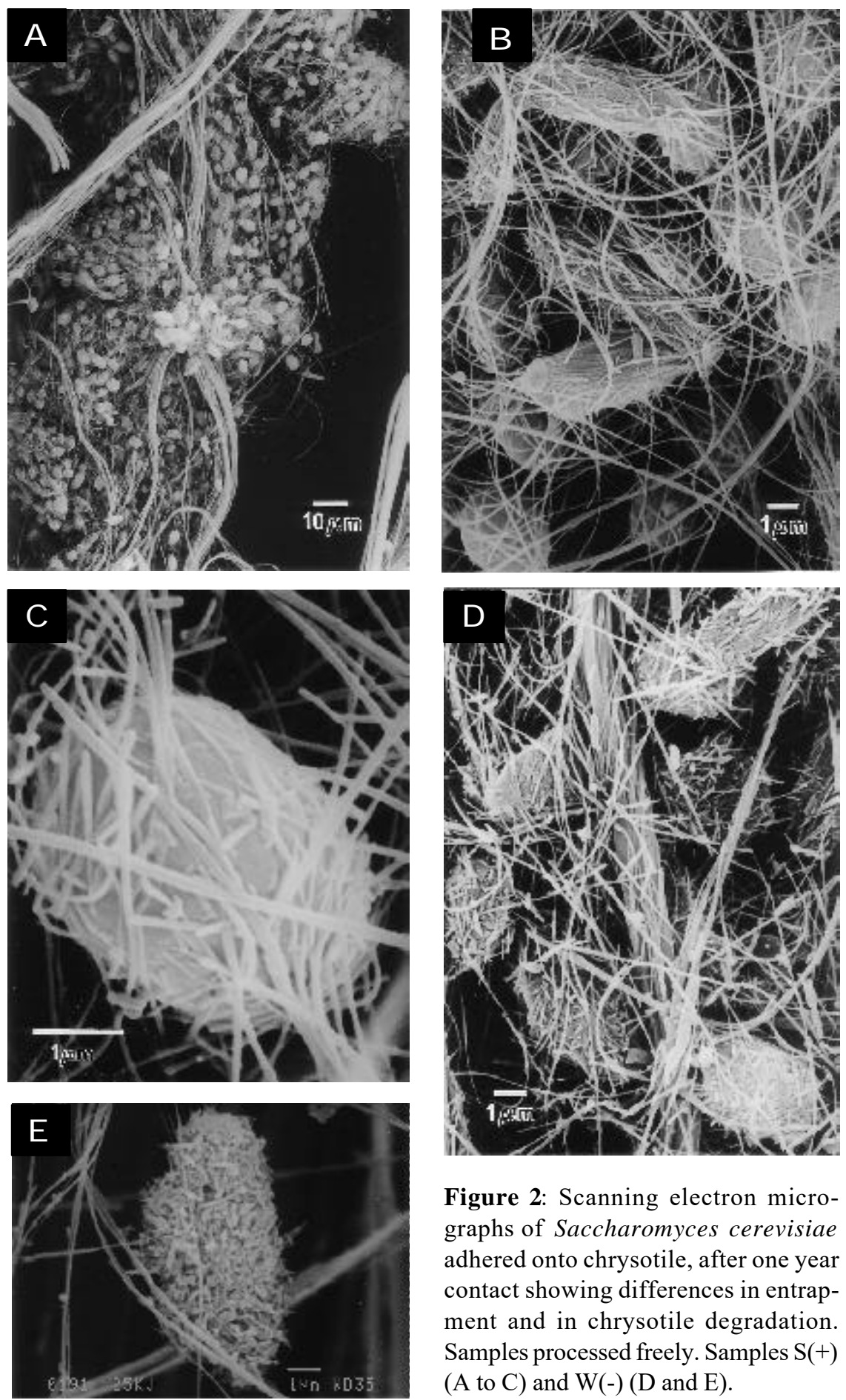

Figure 2: Scanning electron micrographs of Saccharomyces cerevisiae adhered onto chrysotile, after one year contact showing differences in entrapment and in chrysotile degradation. Samples processed freely. Samples $\mathrm{S}(+)$ (A to $\mathrm{C}$ ) and $\mathrm{W}(-)$ (D and $\mathrm{E})$.

Cells adhered during 15 min in the absence of nutrients showed no entrapment following 8-day-storage. On the other hand, in 60-day-storage samples adhered in the absence of nutrients, about $25 \%$ of the cells in the samples were found to be highly entrapped, as shown in Figure 1F. Slower cellular growth should be expected in this case. In fact, no agglomerates of cells were observed, though buds were visible, indicating metabolic activity.

The degree of interaction between the cells and the chrysotile fibres seems to be related both to exposure time and to the presence or absence of nutrients during the adhesion period. The cells seem to have spared nutrients they used during storage time. Cells adhered in the absence of nutrients seem to have used some nutrient from the fibrils more intensely.

Figure 2 shows SEM micrographs of cells adhered to chrysotile fibrils in the presence (A to C) and in the absence (D and E) of nutrients, stored for 1 year. Only cells completely surrounded by fibrils and broken fibrils are present. The overall appearance of the cells is different from that of the 60-day-storage samples shown in Figure 1. Also, the chrysotile fibrils appear degraded in some way, as in Figure 2D and E. A visible difference occurs in the fibrils surrounding the cells, compared to the appearance of the fibrils shown, for instance, in Figure 1. Figure 2E shows an extreme case of fibril degradation by the cells, since no fi- 
brilar structure is recognized covering on the outside of the cells.

The one-year-storage samples adhered in the presence or in the absence of nutrients develop differently, as shown in Figures 2A, 2B and 2C (with), and 2D and 2E (without nutrients). Almost all the cells adhered in the absence of nutrients are covered mostly by broken fibrils (2D and 2E); cells adhered in the presence of nutrients ( $2 \mathrm{~A}$ and $2 \mathrm{C}$ ) were covered to a lesser degree.

Comparing Figures $1 \mathrm{~A}$ with $2 \mathrm{C}$ and $2 \mathrm{E}$, it seems that the fibrils are incorporated in the cell wall. In fact, preliminary results obtained by transmission electron microscopy from ultrathin sections of the cell/chrysotile system (from the samples in Figure 2), show fibrils inside the cell wall.

Figure 2B shows two different shapes of entrapped cells, elongated and spherical-shaped. The elongated cells represent about $30 \%$ of all analyzed samples, and this change of shape may be a consequence of a better adaptation of the cell in the support (Bandypadhyay and Ghose, 1982; Norton and D'Amore, 1994).

The intimate interaction between Saccharomyces cerevisiae and chrysotile fibrils seems to indicate that the material would supply nutritive elements important for the cell's metabolism. A nutrient transfer from fibers to cell can cause the disruption of the fibrillar structure of chrysotile, as shown in Figure 2E. The importance of $\mathrm{Mg}$ for cellular reproduction and fermentative metabolism has been extensively reported in the literature (Walker and Maynard, 1997; Ciesarová et al., 1996), but $\mathrm{Mg}$ alone does not show the same effect as the brucite surface layer of chrysotile for the adhesion of cells (Joekes et al., 1998). Also, Mg uptake by the cells should be much smaller than the quantities available in the chrysotile surface, or in the solution, since $\mathrm{Mg}$ is a metabolic co-factor. It seems that the brucite layer is acting as an adhesive surface, probably through acid-base interactions with the glycoproteins of the cell wall (Kida et al., 1992; Mozes et al., 1987). Besides that, the entrapment can act as a protection for the cells against environmental stress (Ciesarová et al., 1996), once the Saccharomyces cerevisiae cells are still active for fermentation following one-year storage in the absence of nutrients. This protection can be a mechanical protection.

\section{Conclusions}

A specific interaction between Saccharomyces cerevisiae cells and chrysotile fibres is shown. The cells adhere only to fibrils. In the extreme case, the surface becomes totally covered by broken fibrils. The interaction is time dependent. There is no evidence that the fibrils are penetrating the cell, but they seem to be entrapped in the cell wall. Buds grow with fibrils adhered, from the beginning, showing no growing hindrance.

\section{Acknowledgment}

The authors are grateful to SAMA Mineração de Amianto Ltda and CNPq Brazilian Research Council for financial support.

\section{References}

Bandypadhyay KK, Ghose TK (1982) Studies on immobilized Saccharomyces cerevisiae. III Physiology of growth and metabolism on various supports. Biotechnol. Bioeng., 24: 805-15.

Broaddus VC (1997) Asbestos, the mesothelial cell and malignancy: a mater of life or death. Am. J. Respir. Cell Mol. Biol., 17: 657-659.

Ciesarová Z, Smogrovicová D, Dömény Z (1996) Enhancement of yeast ethanol tolerance by calcium and magnesium. Folia Microbiol., 41: 485-88.

Cullen MR (1998) Chrysotile asbestos: enough is enough. The Lancet 351: 1377-1378.

Fukumori N, Aoki N, Sasaki M (1995) Biological effects of ingested asbestos fibers (VII). Finestructural findings of intravenously injected fibers. Ann. Rep. Tokyo Metr. Res. Lab. P.H. 46: 265-270.

Fukumori N, Aoki N, Sasaki M (1996) Electron microscopic observations of asbestos fibers in the rat lung after intratracheal instillation. Ann. Rep. Tokyo Metr. Res. Lab. P.H 47: 303-308.

Fukumori N, Aoki N, Sasaki M (1997) Ultrastructural changes of macrophages on phagocytosis of asbestos fibers. Ann. Rep. Tokyo Metr. Res. Lab. P.H 48: 312-317.

Joekes I, Moran PJS, Rodrigues JAR, Wendhausen R, Tonella E, Cassiola F (1998) Characterization of Saccharomyces cerevisiae immobilized onto chrysotile for ethanol production. J. Chem Technol. Biotechnol., 73: 54-58.

Kida K, Morimura S, Sonoda Y, Yanoh T (1992) The importance of the surface charge on support media for microbial adhesion. J. Ferm. Bioeng, 73: 323-25.

Kogan FM, Nikitina OV (1994) Solubility of chrysotile asbestos and basalt fibers in relation to their fibrogenic and carcinogenic action. Environ. Health Perspect. 102: 205-206.

Langer AM, Nolan RP (1994) Chrysotile biopersistence in the lungs of persons in the general population and exposed workers. Environ. Health Perspect. 102: 235-239.

Mozes N, Marchal F, Hermesse MP, Van Haecht JL, Reuliaux L, Leonard AJ, Rouxhet PG (1987) Immobilization of microorganisms by adhesion: interplay of electrostatic and nonelectrostatic interactions. Biotechnol. Bioeng., 30: 439-450.

Nolan R P, Langer AM, Addison J (1994) Lung content analysis of cases occupationally exposed to chrysotile asbestos. Environ. Health Perspect. 102: 245-250.

Norton S, D'Amore T (1994) Physiological effects of yeast cell immobilization: applications for brewing. Enzyme Microb. Technol. 16: 365-375.

Parizotto O, Comerlato MH, Pedroso PR, Moran PJS, Carvalho M, Joekes I (1989) Preparation of chrysotile with high specific surface area. Pat. BR. 8903849.

Walker GM, Maynard A (1997) Accumulation of magnesium ions during fermentative metabolism in Saccharomyces cerevisiae. J. Industrial Microbiol. Biotechnol., 18: $1-3$.

Wendhausen R, Moran PJS, Joekes I, Rodrigues JAR (1998) Continuous process for large-scale preparation of chiral alcohols with baker's yeast immobilized on chrysotile fibers. J. Mol. Cat. B: Enzymatic, 5: 57-61. 


\section{Discussion with Reviewers}

D.M. Bernstein: Is there any reason to expect that the results seen here with Saccharomyces cerevisiae would have a parallel with mammalian cells, in particular alveolar macrophages? If so, then the authors should develop this point in the discussion.

Authors: The interaction shown in this paper for Saccharomyces cerevisiae and chrysotile is rather different from that shown by Fukumori et al. (1997). These authors show SEM micrographs of macrophage phagocytosis of asbestos fibers (chrysotile, tremolite and amosite). In their micrographs, it is quite clear that the fibrils are entering the cell envelope. In our micrographs, the fibrils are distinguishable on the cell wall. In other words, the interaction between Saccharomyces cerevisiae and chrysotile is mainly adhesive.

G. Griffiths: I am surprised by the changes that are visible between 8 days and 60 days (Fig. 1) given that the cells would have reached stationary phase after a few days and would not be expected to be metabolically active thereafter (especially in the fridge). Was there any evidence of yeast cell death or degradation?

Authors: We have no evidence of yeast cell death or degradation in any sample. Samples stored for three years have the characteristic odour of fermentation, indicating that the cells are viable.

G. Griffiths: Did the authors examine the fibres embedded in cell wall at higher magnification?

Authors: We are now studying ultrathin sections of the Saccharomyces cerevisiae / chrysotile system by transmission electron microscopy. Preliminary results show that the chrysotile fibres adhere to the first layer of the cell wall. By now, no significant differences in the ultrastructure of the chrysotile fibrils have been observed.

G. Griffiths: Could the degradation of the chrysotile strands be due to the activity of organic acids produced by the yeast?

Authors: We do not know. After the adhesion process, every cell metabolite permeated through the membrane will get in contact with the attached fibrils. If the cell/fibrils system is kept in water, the metabolites will be diluted, but in a water-deficient medium, their concentration could be high enough to cause chemical aggression.

I. ap Gwynn: Why did the authors use a $25 \mathrm{kV}$ accelerating voltage? The images shown show lack of detail in the filamentous structures that is a direct consequence of using such a high $\mathrm{kV}$. We have found that the JEOL 840 performs very much better on such specimens at around $5 \mathrm{kV}$ - provided the working distance is reduced to about $6 \mathrm{~mm}$. Authors: We have used $25 \mathrm{kV}$ for most part on the work, to obtain a higher contrast. Chrysotile fibrils look smooth, without details on their surface, even in the TEM.

G.M. Roomans: The authors conclude that yeast cells can partially degrade chrysotile fibers. Strictly speaking, this conclusion would require a control incubation without cells, Was such a control carried out?

Authors: No. However, our samples had fibrils which were not attached to the yeast cells, and these showed no degradation, as can be seen in Figure 2.

G.M. Roomans: Apparently, the authors did not study any chemical changes in the fibres, e.g., by X-ray microanalysis, which is a pity. This would have been useful in view of their speculation of the possible use of $\mathrm{Mg}$ by the cells. Authors: TEM X-ray microanalysis results were inconclusive. However, if the cells remove only the external brucite layer, the overall $\mathrm{Mg}$ content will change by only a small fraction.

G.M. Roomans: Could the authors provide any suggestions as to how the chrysotile is biodegraded by the yeast cells?

Authors: No. Chemically, it is easy to explain how the cells would degrade the brucite layers, which are known as unstable as magnesium hydroxide itself. But the silica layers left behind should be quite stable. Moreover, if the brucite layers are degraded, the fibril diameter must increase appreciably, which is not observed. 